\title{
A Genomic Point Mutation in the Extracellular Domain of the Thyrotropin Receptor in Patients with Graves' Ophthalmopathy*
}

\author{
REBECCA S. BAHN, CHARYL M. DUTTON, \\ ARMIN E. HEUFELDER, AND GOBINDA SARKAR \\ Division of Endocrinology, Departments of Internal Medicine and Orthopedic Research, Mayo Clinic/ \\ Foundation, Rochester, Minnesota 55905; and the Molecular Thyroid Research Laboratory, Mediziniche \\ Klinik, Klinikum Innenstadt, Ludwig-Maximilians-Universitat, 80336 Munich, Germany
}

\begin{abstract}
Orbital and pretibial fibroblasts are targets of autoimmune attack in Graves' ophthalmopathy (GO) and pretibial dermopathy (PTD). The fibroblast autoantigen involved in these peripheral manifestations of Graves' disease and the reason for the association of GO and PTD with hyperthyroidism are unknown. RNA encoding the full-length extracellular domain of the TSH receptor has been demonstrated in orbital and dermal fibroblasts from patients with GO and normal subjects, suggesting a possible antigenic link between fibroblasts and thyrocytes.

RNA was isolated from cultured orbital, pretibial, and ahdominal fibroblasts obtained from patients with severe $\mathrm{GO}(\mathrm{n}=22)$ and normal subjects $(n=5)$. RNA was reverse transcribed, and the resulting cDNA was amplified by the polymerase chain reaction, using primers spanning overlapping regions of the entire extracellular domain of the TSH
\end{abstract}

receptor. Nucleotide sequence analysis showed an $\mathrm{A}$ for $\mathrm{C}$ substitution in the first position of codon 52 in 2 of the patients, both of whom had GO, PTD, and acropachy. Genomic DNA isolated from the 2 affected patients, and not from an additional 12 normal subjects, revealed the codon 52 mutation by direct sequencing and AciI restriction enzyme digestions.

In conclusion, we have demonstrated the presence of a genomic point mutation, leading to a threonine for proline amino acid shift in the predicted peptide, in the extracellular domain of the TSH receptor in two patients with severe GO, PTD, acropachy, and high thyroidstimulating immunoglobulin levels. RNA encoding this mutant product was demonstrated in the fibroblasts of these patients. We suggest that the TSH receptor may be an important fibroblast autoantigen in GO and PTD, and that this mutant form of the receptor may have unique immunogenic properlies. (J Clin Endocrinol Metab 78: 256-260, 1994)
$\mathrm{O}$ RBITAL and pretibial fibroblasts are targets of autoimmune attack in Graves' ophthalmopathy (GO) and pretibial dermopathy (PTD) (1). However, the association of the hyperthyroidism of Graves' disease with these connective tissue-based extrathyroidal manifestations has long been enigmatic. We have shown previously that fibroblasts contain RNA encoding the extracellular domain of the TSH receptor (2). Similar findings (in retroorbital tissue samples) have been reported by another group (3). If translated into protein, this fibroblast autoantigen might be recognized by lymphocytes directed against the TSH receptor in Graves' disease. The subsequent infiltration of the orbit and skin by activated cytokine-producing lymphocytes would probably stimulate glycosaminoglycan synthesis and proliferation of the resident fibroblasts (1). The resulting histological changes would be those characteristic of the involved tissues in GO and PTD (4).

Autoantigens are expected to be normal in autoimmune diseases; the abnormality is most likely to be found in the immune system itself. However, a somatic point mutation in the extracellular domain of the TSH receptor has been re-

Received August 20, 1993. Accepted October 29, 1993.

Address all correspondence and requests for reprints to: $R$. S. Bahn, M.D., Division of Enducrinology, Mayo Clinic/Foundation, Rochester, Minnesota 55905.

* This work was supported by NIH Research Grant EY-O8819 from the National Eye Institute (Bethesda, MD). ported in thyroid RNA of a patient with Graves' disease (5). As the somatic mutation is located in a putative ligandbinding domain, the researchers speculated that the mutation has a causal relationship to the patient's thyroid disorder. We wished to determine whether there might be a mutation in the TSH receptor gene in fibroblasts of patients with GO. In this study we demonstrate a genomic point mutation in the extracellular domain of the TSH receptor in two patients with GO, PTD, acropachy, and high thyroid-stimulating immunoglobulin (TSI) levels. RNA encoding the product of this mutant gene is present in fibroblasts from these patients. Because of the high levels of antibody activity directed against the TSH receptor in these two patients and the severity of their connective tissue manifestations, we hypothesize that the protein product of their mutant TSH receptor gene may have unique immunogenic properties.

\section{Materials and Methods}

\section{Subjects}

Orbital connective tissue was obtained from patients with severe GO $(n=22)$ in the course of transantral orbital decompression surgery (see Table 1 for clinical details). Normal orbital connective tissue was obtained from individuals with no history of thyroid disease who underwent orbital surgery for unrelated conditions $(n=5)$. Pretibial $(n=2)$ and abdominal ( $n=1$ ) skin biopsies were obtained by written consent and Institutional Review Board approval from two of the patients with GO who also had PTD (patients 1 and 18; Table 1). In addition, a fine 
TABLE 1. Clinical characteristics and TSH receptor analysis in 22 patients with severe GO

\begin{tabular}{rrlcccc}
\hline $\begin{array}{c}\text { Patient } \\
\text { no. }\end{array}$ & $\begin{array}{c}\text { Age } \\
\text { (yr) }\end{array}$ & Sex & $\begin{array}{c}\text { Presence of } \\
\text { PTD }\end{array}$ & $\begin{array}{c}\text { Presence of } \\
\text { acropachy }\end{array}$ & $\begin{array}{c}\text { TSI } \\
\text { index }\end{array}$ & $\begin{array}{c}\text { Presence of } \\
\text { codon 52 } \\
\text { mutation }\end{array}$ \\
\hline 1 & 39 & F & + & + & 16 & + \\
2 & 67 & F & - & - & ND $^{b}$ & - \\
3 & 34 & M & - & - & 8.9 & - \\
4 & 34 & F & + & - & 1.9 & - \\
5 & 58 & F & + & + & ND & - \\
6 & 50 & F & + & + & 22 & + \\
7 & 65 & F & - & - & ND & - \\
8 & 55 & F & + & - & 19 & - \\
9 & 85 & F & - & - & ND & - \\
10 & 55 & M & - & - & 8.4 & - \\
11 & 45 & F & - & - & 13 & - \\
12 & 68 & M & - & - & 17 & - \\
13 & 64 & M & - & - & 9.4 & - \\
14 & 62 & F & - & - & 8.7 & - \\
15 & 45 & F & - & - & 18 & - \\
16 & 63 & F & - & - & 14 & - \\
17 & 53 & F & - & - & 8.7 & - \\
18 & 55 & M & + & - & 17 & - \\
19 & 51 & F & - & - & 8.8 & - \\
20 & 54 & F & - & - & 5.7 & - \\
21 & 61 & M & - & - & 6.4 & - \\
22 & 50 & F & + & + & 15 & - \\
\hline
\end{tabular}
1.3).

${ }^{a}$ TSI index at time of orbital decompression surgery (normal $=0.0-$ ${ }^{\circ}$ Not done.

needle aspiration biopsy of the thyroid was obtained from patient 1 . Peripheral blood samples were collected from additional patients with severe GO $(n=3)$ and normal subjects $(n=12)$. Peripheral blood mononuclear cells (PBMC) were isolated from whole blood using standard procedures (6). Serum TSI activity was determined using a standard assay that measures cAMP generation in cultured FRTL- 5 thyroid cells (7).

\section{Cell culture}

Fibroblast cultures were established from biopsy specimens, as described previously (8). Briefly, tissue explants were minced and placed directly on plastic culture dishes, and fibroblasts were allowed to proliferate. Fibroblast cultures were propagated in medium 199 containing $20 \%$ fetal bovine serum (HyClone Laboratories, Logan, UT), penicillin $(100 \mathrm{IU} / \mathrm{mL})$, and gentamycin $(20 \mu \mathrm{g} / \mathrm{mL})$ in a humidified $5 \% \mathrm{CO}_{2}$ incubator at $37 \mathrm{C}$. All cell cultures established in this fashion stain positively for a specific antifibroblast antigen (Dakopatts Corp., Santa Barbara, CA). Cultures were maintained in $75-\mathrm{mm}^{2}$ flasks with medium 199 containing $10 \%$ fetal bovine serum and were used between the first and fifth passages. Cultured Chinese hamster ovary $(\mathrm{CHO})$ cells, transfected with either plasmid containing the human TSH receptor (JPO9 line) or the untransfected counterpart $\left(\mathrm{JPO}_{2}\right.$ line) (9), and Fisher rat thyroid cells (FRTL-5, CRL 8305, American Type Culture Collection, Rockville, MD) were used as control cell lines.

\section{RNA/DNA amplification with transcript sequencing}

Total RNA was isolated directly from $1 \times 10^{6}$ fibroblast cells using guanidinium thiocyanate and cesium chloride (10). First strand CDNA synthesis was performed using $20 \mu \mathrm{g}$ heat-denatured total RNA and random hexamers (11). The resulting CDNA was amplified by the polymerase chain reaction (PCR) with primers spanning overlapping regions of the entire extracellular domain of the TSH receptor. Oligonucleotide primers 2 and 3 were used for amplification of the CDNA fragment containing the base pair (bp) substitution (Table 2). PCR amplification was performed with $4 \mu \mathrm{L}$ CDNA template and $5.0 \mathrm{pmol}$ of each PCR primer in $10 \mathrm{mmol}$ Tris- $\mathrm{HCl}(\mathrm{pH} 8.3), 50 \mathrm{mmol} \mathrm{KCl}, 1.5 \mathrm{mmol}$ $\mathrm{MgCl}_{2}, 200 \mu \mathrm{mol} / \mathrm{L}$ of each deoxy-NTP, and $1 \mathrm{U}$ Ampli-Taq DNA
TABLE 2. Oligonucleotide sequences and descriptions of primers

\begin{tabular}{|c|c|c|}
\hline $\begin{array}{c}\text { Primer } \\
\text { no. }\end{array}$ & Oligonucleotide sequence & Description ${ }^{\alpha}$ \\
\hline 1 & $\begin{array}{l}\text { 5'-TAATACGACTCACTATAG- } \\
\text { GGAGATCCCGTGGAAAAT- } \\
\text { GAGGCC-3' }\end{array}$ & $\begin{array}{l}\text { Residues } 90-108: \\
\text { sense strand }\end{array}$ \\
\hline 2 & $\begin{array}{l}\text { 5'-ATTTAGGTGACACTATAG- } \\
\text { AATACTCCCGTGGAAAAT- } \\
\text { GAGGCC-3' }\end{array}$ & $\begin{array}{l}\text { Residues }-90-108 \text { : } \\
\text { sense strand }{ }^{c}\end{array}$ \\
\hline 3 & $\begin{array}{l}\text { 5' -TAATACGACTCACTATAG- } \\
\text { GGAGACAGGTGTTTCTTG- } \\
\text { CTATCAG-3' }\end{array}$ & $\begin{array}{l}\text { Residues 854-873: } \\
\text { antisense strand }\end{array}$ \\
\hline 4 & $\begin{array}{l}\text { 5'-TAATACGACTCACTATAG- } \\
\text { GGAGAAAATGCATGACTT- } \\
\text { GGAAT- } 3^{\prime}\end{array}$ & $\begin{array}{l}\text { Residues } 299-316 \text { : } \\
\text { antisense } \\
\text { strand }^{b}\end{array}$ \\
\hline 5 & $\begin{array}{l}\text { 5'-CATACACATACGATTTAG- } \\
\text { GTGACACTATAGAATACA- } \\
\text { GAGTCTGCGTACTGG-3' }\end{array}$ & $\begin{array}{l}\text { Residues 255-270: } \\
\text { antisense } \\
\text { strand }^{d}\end{array}$ \\
\hline
\end{tabular}

polymerase (Perkin-Elmer/Cetus, Norwalk, CT) in a final volume of 50 $\mu \mathrm{L}$. The amplification reaction for cDNA was 35 cycles (Perkin-Elmer thermal cycler 801-0150); each cycle consisted of $94 \mathrm{C}$ for $1 \mathrm{~min}$ (denaturation), $55 \mathrm{C}$ for $2 \mathrm{~min}$ (annealing), and $72 \mathrm{C}$ for $3 \mathrm{~min}$ (elongation), followed by a final 10 -min extension at $72 \mathrm{C}$.

Genomic DNA was isolated and purified from $1 \times 10^{5}$ fibroblasts or PBMC from $7 \mathrm{~mL}$ whole blood by standard procedures (6). In addition, genomic DNA was isolated from cells obtained by a thyroid fine needle aspiration and digested with proteinase-K (12). The procedure for amplification of genomic DNA was identical to that described above, except that $1 \mu \mathrm{L}$ DNA and PCR primers 1 and 5 (Table 2; 2.5 pmol each) were amplified using $0.5 \mathrm{U}$ Ampli-Taq polymerase in a total volume of $20 \mu \mathrm{L}$; the annealing temperature was $55 \mathrm{C}$. For the thyroid fine needle aspiration sample, $20 \mu \mathrm{L}$ cell lysate were amplified with PCR primers 2 and 4 (50 pmol each) and $2 U$ Ampli-Taq DNA polymerase in a total volume of $80 \mu \mathrm{L} ; 4 \mu \mathrm{L}$ of this product were reamplified with primers 1 and 5 (10 pmol each) and $1 \mathrm{U}$ Ampli-Taq DNA polymerase in a total volume of $50 \mu \mathrm{L}$. Amplification reaction conditions were the same as described above.

For direct sequencing of amplified segments from cDNA or genomic DNA, $3 \mu \mathrm{L}$ of the amplified material were added to $17 \mu \mathrm{L}$ transcription mixture [40 mmol/L Tris- $\mathrm{HCl}(\mathrm{pH} 7.5), 6 \mathrm{mmol} / \mathrm{L} \mathrm{MgCl}_{2}, 2 \mathrm{mmol} / \mathrm{L}$ spermidine, $10 \mathrm{mmol} / \mathrm{L} \mathrm{NaCl}, 0.5 \mathrm{mmol} / \mathrm{L}$ of each ribonucleoside triphosphate, $1.6 \mathrm{U} / \mathrm{mL}$ RNasin, $10 \mathrm{mmol} / \mathrm{L}$ dithiothreitol (DTT), $10 \mathrm{U}$ T7 RNA polymerase, and diethylpyrocarbonate-treated $\mathrm{H}_{2} \mathrm{O}$ ] (13). Samples were incubated for $1 \mathrm{~h}$ at $37 \mathrm{C}$, and the reaction was stopped by heating at $65 \mathrm{C}$ for $10 \mathrm{~min}$. A $2-\mu \mathrm{L}$ aliquot of the transcription reaction was added to $10 \mu \mathrm{L}$ annealing buffer $(250 \mathrm{mmol} / \mathrm{L} \mathrm{KCl}$ and $10 \mathrm{mmol} / \mathrm{L}$ Tris$\mathrm{HCl}, \mathrm{pH} \mathrm{8.3)}$ containing a ${ }^{32} \mathrm{P}$ end-labeled reverse transcription primer. Samples were heated at $80 \mathrm{C}$ for $3 \mathrm{~min}$ and then annealed for $45 \mathrm{~min}$ at $45 \mathrm{C}$. A $2-\mu \mathrm{L}$ aliquot of the primer RNA template solution was added to $3.3 \mu \mathrm{L}$ reverse transcriptase buffer $[24 \mathrm{mmol} / \mathrm{L}$ Tris- $\mathrm{HCl}(\mathrm{pH} 8.3), 16$ $\mathrm{mmol} / \mathrm{L} \mathrm{MgCl}, 8 \mathrm{mmol} / \mathrm{L}$ DTT, $0.4 \mathrm{mmol} / \mathrm{L}$ of each deoxyribonucleoside triphosphate, and $0.4 \mathrm{mmol} / \mathrm{L}$ thymidine triphosphate] containing $5 \mathrm{U}$ avian myeloma virus reverse transcriptase and $1 \mu \mathrm{L}$ of a dideoxyribonucleoside triphosphate. The sample was incubated at $50 \mathrm{C}$ for 45 min, and the reaction was stopped by adding $2.5 \mu \mathrm{L}$ formamide (100\%) with bromophenol blue $(0.3 \%)$ and xylene cyanol FF. Samples were boiled for $3 \mathrm{~min}$, and a $1.5-\mu \mathrm{L}$ aliquot was loaded onto a $100-\mathrm{cm}$ sequencing gel and separated by electrophoresis $(\sim 15,000 \mathrm{~V}-\mathrm{h})$. Autoradiography was performed, and gels were read manually. 


\section{Restriction enzyme digestions}

Each cDNA amplification product $(20 \mu \mathrm{L})$ was digested at $37 \mathrm{C}$ overnight in $1 \times \mathrm{NEB}$ buffer $3(100 \mathrm{mmol} \mathrm{NaCl}, 50 \mathrm{mmol}$ Tris- $\mathrm{HCl}, 10$ mmol $\mathrm{MgCl}_{2}$, and $1 \mathrm{mmol} \mathrm{DTT}$, pH 7.9, at $25 \mathrm{C}$ ) with $15 \mathrm{U}$ Acil enzyme (551S, New England Biolabs, Inc., Beverly, MA) in a total reaction volume of $30 \mu \mathrm{L}$. Digestion products $(15 \mu \mathrm{L})$ were resolved on $2 \%$ agarose gels (wild-type cDNA produces fragments of 44, 49, 92, and $642 \mathrm{bp}$; mutant cDNA produces fragments of 734, 44, and $49 \mathrm{bp}$; undigested cDNA fragment is $827 \mathrm{bp}$ ). The digestion of the amplified product from genomic DNA was identical, except that each amplification product $(10 \mu \mathrm{L})$ was digested with $10 \mathrm{U}$ AciI enzyme in a total reaction volume of $20 \mu \mathrm{L}$ that was entirely loaded onto a $4 \%$ agarose gel (fragments from wild-type DNA are 44, 49,55, and 92 bp; mutant DNA produces fragments of 146,44 , and 49 bp; undigested DNA fragment is $240 \mathrm{bp})$.

\section{Results}

For the PCR-based amplification of TSH receptor RNA, primers were designed to amplify overlapping fragments of cDNA encompassing the full-length extracellular domain of the TSH receptor. The entire 1183-bp extracellular domain was sequenced using RNA derived from cultured retroocular fibroblasts obtained from 22 patients with GO and 5 normal subjects and from cultured pretibial $(n=2)$ and abdominal $(n=1)$ skin fibroblasts from 2 of the patients with GO who also had PTD (patients 1 and 18; Table 1). In each sample, we found nucleotide sequence corresponding to the fulllength extracellular domain reported by Nagayama et al. (14), except for an A for C substitution in the first position of codon 52 that was present in fibroblast RNA samples from 2 of the patients studied (patients 1 and 6; Fig. 1). The wild-type receptor sequence (CCC at codon 52) was also present in each of these 2 samples. The reverse transcription step and cDNA amplification were repeated several times with identical results in both of these patients. The presence of the mutation was subsequently verified in RNA from both patients using AciI restriction enzyme digestions of amplified cDNA (Fig. 2). This mutation leads to a threonine for proline amino acid shift in the predicted peptide. Proline, the wildtype amino acid at codon 52, is highly conserved; its presence in this position has been demonstrated in both the rat (15) and dog (16) TSH receptor sequences.

To determine whether the mutation in codon 52 of the $\mathrm{TSH}$ receptor is a germline mutation, we examined genomic DNA from patients 1 and 6 (Table 1). Acil restriction enzyme digestions of amplified genomic DNA from patient 1 demonstrated both the wild-type and the mutant nucleotide sequences at the first position of codon 52 in cultured retroocular, pretibial skin, and abdominal skin fibroblasts; cells
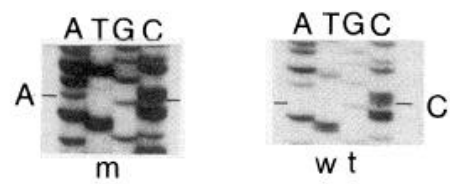

FIG. 1. Sequence analysis of the two forms of TSH receptor. Amplified PCR fragments from cDNA template were sequenced as described in Materials and Methods. The wild-type (wt) form has a cystine at the first position of codon 52 (noted by markers; right). The mutant (m) form (cDNA template was derived from patient 1 ) has both a cystine and an adenine at this position (left).

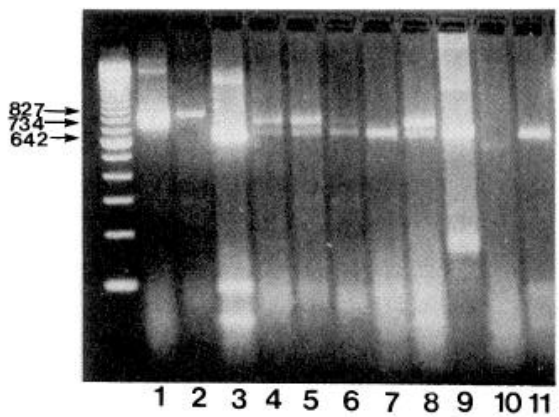

FIG. 2. AciI restriction enzyme digestions of PCR fragments amplified from cDNA templates. The undigested fragment size is $827 \mathrm{bp}$. AciI digestion of wild-type sequence produces $642-, 92-, 49-$, and $44-b p$ fragments; the mutant allele produces an additional 734-bp fragment. Derivation of cDNA templates in lanes following the 100-bp ladder is as follows: 1) JP09 (TSH receptor-positive CHO cells; undigested), 2) patient 1 (undigested), 3) JP09, 4) patient 1 orbital fibroblasts, 5) patient 1 pretibial skin fibroblasts, 6) patient 1 abdominal skin fibroblasts, 7) orbital fibroblasts from a normal subject, 8) patient 6 orbital fibroblasts, 9) rat thyroid cells (FRTL-5), 10) JP02 (TSH receptornegative $\mathrm{CHO}$ cells), and 11) patient 8 orbital fibroblasts.

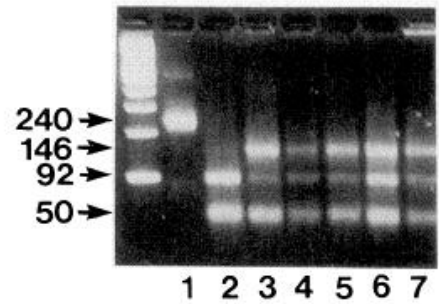

FIG. 3. AciI restriction enzyme digestions of PCR fragments amplified from genomic DNA template from patient 1 . The undigested fragment is $240 \mathrm{bp}$. AciI digestion of wild-type sequence produces fragments of $44,50,54$, and $92 \mathrm{bp}$; the mutant allele produces an additional 146-bp band. Derivation of genomic DNA templates in lanes following the 100-bp ladder are as follows: 1) patient 1 orbital fibroblasts (undigested), 2) orbital fibroblasts from a normal subject, 3) patient 1 orbital fibroblasts, 4) patient 1 pretibial fibroblasts, 5) patient 1 abdominal fibroblasts, 6) patient 1 thyroid fine needle aspiration sample, and 7) patient 1 PBMC.

from a thyroid fine needle aspiration sample; and PBMC (Fig. 3). The reproducible findings of the mutation in cells from several sites obtained from the same patient and its consistent heterozygosity, mitigate strongly against a Taq polymerase error being responsible for these results.

The same restriction enzyme digestion strategy was used to examine genomic DNA from PBMC of 12 normal subjects. None was found to have the mutation at codon 52 . These 12 normal subjects, in addition to the 5 normal subjects whose fibroblast RNA was entirely sequenced in the area of codon 52, bring to a total of 17 the normal subjects studied; none had the mutation.

In addition to the mutation in the first position of codon 52 , we observed a polymorphism at nucleotide position 661 (third position of codon 187). We found 13 of 22 patients with GO to be homozygous for thymidine at this position, 1 GO patient was homozygous for cytosine, and the remaining GO patients were heterozygous (thymidine/cytosine) at 661 . Four of the normal subjects were homozygous for thymidine at nucleotide position 661; the remaining normal subject was heterozygous (thymidine/cytosine). We consider this varia- 
tion, found in both normal individuals and GO patients, to be a polymorphism because it would not result in a change in the wild-type amino acid (asparagine) at codon 187.

\section{Discussion}

We report the presence of a germline mutation in the first position of codon 52 of the TSH receptor in two patients with severe GO, PTD, acropachy, and high TSI levels. Several groups of investigators have identified regions on the $\mathrm{N}$-terminal region of the extracellular domain of the TSH receptor that appear to have epitopes for binding of TSH or antibodies directed against this receptor. Amino acid residues 30-33, 34-37, 42-45, 52-56, and 58-61 (17); 32-56 (18); and 38-45 (19) have been specifically implicated as important stimulatory antibody-binding regions. However, it is likely that these epitopes are conformational and include multiple discontinuous regions spanning the entire extracellular domain (19), and perhaps the extracellular loops of the transmembrane domains, of the TSH receptor (18-21). The mutation described in our study would lead to a threonine for proline shift in amino acid residue 52. It is possible that the substitution of threonine (a neutral and polar amino acid) for proline (a neutral and hydrophobic amino acid) would result in a conformational change in the extracellular portion of the TSH receptor. Such a change could alter the immunogenicity or function of this protein.

The finding of mRNA for the TSH receptor in fibroblasts using PCR does not guarantee the presence of functional or immunologically active TSH receptor protein in these cells. Indirect evidence for the presence of this receptor on fibroblasts is suggested by our finding of enhanced expression of adhesion molecules (22) and a 72-kilodalton heat shock protein (23) after treatment of human retroocular fibroblast cultures with immunoglobulin $\mathrm{G}$ derived from patients with GO and high TSI levels. More direct evidence has been forwarded by Burch and colleagues (24), who demonstrated binding of polyclonal rabbit antiserum directed against a TSH receptor peptide (amino acid residues 352-367) in cultured retroocular fibroblasts. Reversible low affinity binding of $\left[{ }^{125} \mathrm{I}\right]$ bovine TSH has been detected on porcine orbital connective tissue membranes (25).

Acropachy is a rare connective tissue manifestation of Graves' disease. Clinical features include drumstick clubbing of the digits, reticular subperiosteal new bone formation, and soft tissue swelling that is similar histologically to that seen in pretibial skin in PTD (4). In most instances, the peripheral manifestations of Graves' disease develop in hierarchy; GO is the first presentation, PTD develops next, and finally, acropachy may occur when the disease is quite prolonged or intense. It is of interest that both patients found to have the codon 52 mutation also have PTD and acropachy. In addition, these patients had among the highest TSI levels measured in our study. We hypothesize that these two patients may have a particularly intense autoimmune response directed against their TSH receptor, leading to the high TSI levels and remarkable clinical features. It may be that their mutant form of the TSH receptor is particularly immunogenic.
This is the first report, to our knowledge, of a germline mutation in the TSH receptor. Point mutations causing amino acid substitutions in membrane proteins have been causally implicated in the pathogenesis of autosomal dominant diseases, including Charcot-Marie-Tooth disease type IA (26) and hyperkalemic periodic paralysis (27). In the latter disease, mutations affecting transmembrane domains of a skeletal muscle sodium channel gene product have been identified, the presence of which presumably alters sodium channel properties leading to the disease. However, the mechanism by which a point mutation with a resulting amino acid substitution might lead to an autoimmune disease is unclear, and there exists no precedent in other autoimmune diseases.

Although various HLA-DR antigens (especially HLA-DR3) are associated with GO (28), no particular gene has been shown to confer strong susceptibility for the condition. Evidence suggests that a permissive genetic background, in addition to the presence of certain environmental factors, may be necessary for the full clinical expression of GO in patients with Graves' disease. It may be that the presence of the codon 52 mutation along with particular HLA haplotypes and environmental factors leads to an especially intense autoimmune reaction directed against TSH receptors. This reaction may be appreciated clinically as severe connective tissue involvement in Graves' disease. It is of note that neither of the patients found to have the mutation related a family history of thyroid disease. Further, two of the patients studied (patients 5 and 22) had PTD and acropachy, but did not have a TSH receptor extracellular domain mutation. Perhaps the codon 52 mutation is only one of several permissive factors involved in the development of the severe connective tissue manifestations of Graves' disease. An understanding of the potential pathogenic importance of this mutation awaits further study.

\section{Acknowledgments}

The authors are grateful to Dr. James Garrity, Department of Ophthalmology, Mayo Clinic, for supplying the surgical eye tissue, and to Dr. Gilbert Vassart, Brussels, Belgium, for supplying the transfected $\mathrm{CHO}$ cells.

\section{References}

1. Bahn RS, Heufelder AE. 1993 Pathogenesis of Graves' ophthalmopathy. N Engl J Med. 20:1468-1475.

2. Heufelder AE, Dutton CM, Sarkar G, Donovan KA, Bahn RS. 1993 Detection of TSH receptor RNA in cultured fibroblasts from patients with Graves' ophthalmopathy and pretibial dermopathy Thyroid. 3:297-300.

3. Feliciello A, Porcellini A, Ciullo I, Bonavolonta G, Avvedimento EV, Fenzi G. 1993 Expression of thyrotropin-receptor mRNA in healthy and Graves' disease retro-orbital tissue. Lancet. 342:337338.

4. Smith TJ, Bahn RS, Gorman CA. 1989 Connective tissue glycosaminoglycans and diseases of the thyroid. Endocr Rev. 10:366-391.

5. Heldin NE, Gustavsson B, Westermark K, Westermark B. $1990 \mathrm{~A}$ somatic point mutation in a putative legand binding domain of the TSH receptor in a patient with autoimmune hyperthyroidism. J Clin Endocrinol Metab. 73:1374-1376.

6. Gustafson S, Proper JA, Bowie EJW, Sommer SS. 1977 Parameters affecting the yield of DNA from human blood. Anal Biochem. 
165:294-299

7. Vitti P, Rotella CM, Valente WA, et al. 1983 Characterization of the optimal stimulatory effects of Graves' monoclonal and serum immunoglobulin $\mathrm{G}$ on adenosine $3^{\prime}, 5^{\prime}$ monophosphate production in FRTL5 thyroid cells: a potential clinical assay. J Clin Endocrinol Metab. 57:782-791.

8. Bahn RS, Gorman CA, Woloschak GE, David CS, Johnson PM, Johnson CM. 1987 Human retroocular fibroblasts in vitro: a model for the study of Graves' ophthalmopathy. J Clin Endocrinol Metab. 65:665-670

9. Perret J, Ludgate M, Libert F, et al. 1990 Stable expression of the human TSH receptor in CHO cells and characterization of differentially expressing clones. Biochem Biophys Res Commun. 171:1044-1050.

10. Maniatis T, Fritsch EF, Sambrook J. 1982 Extraction, purification, and analysis of mRNA from eukaryotic cells. In: Ford N, Nolan C, eds. Molecular cloning-a laboratory manual. Cold Spring Harbor: Cold Spring Harbor Laboratory; 196.

11. Sommer SS, Sarkar G, Koeberl DD, et al. 1990 Direct sequencing with the aid of phage promoters. In: Innis M, Gelfand DH, Sninsky JJ, White TJ, eds. PCR protocols: a guide to methods and applications. New York: Academic Press; 197-205.

12. Kovach JS, McGovern RM, Cassady JD, et al. 1991 Direct sequencing from touch preparations of human carcinomas: analysis of $\mathrm{p} 53$ mutations in breast carcinomas. J Natl Cancer Inst. 83:1004-1009.

13. Sarkar G, Sommer SS. 1988 RNA amplification with transcript sequencing (RAWTS). Nucleic Acids Res. 16:5197.

14. Nagayama Y, Kaufman KD, Seto P, Rapaport B. 1989 Molecular cloning, sequence and functional expression of the cDNA for the human thyrotropin receptor. Biochem Biophys Res Commun. 165:1184-1190.

15. Akamizu T, Ikuyama S, Saji M, et al. 1990 Cloning, chromosomal assignment, and regulation of the rat thyrotropin receptor by thyrotropin, agents which increase cAMP levels and thyroid autoantibodies. Proc Natl Acad Sci USA. 87:5677-5681.

16. Parmentier M, Libert F, Maenhaut C, et al. 1989 Nucleotide sequence of the dog thyrotropin receptor cDNA. Nucleic Acids Res. 17:10493.
17. Kosugi S, Ban T, Kohn LD. 1993 Identification of thyroid stimulating antibody-specific interaction sites in the $\mathrm{N}$-terminal region of the thyrotropin receptor. Mol Endocrinol. 7:114-130.

18. Murakami M, Mori M. 1990 Identification of immunogenic regions in human thyrotropin receptor for immunoglobulin $G$ of patients with Graves' disease. Biochem Biophys Res Commun. 171:512-519.

19. Nagayama Y, Rapoport B. 1992 The thyrotropin receptor 25 years after its discovery: new insight after its molecular cloning. Mol Endocrinol. 6:145-156.

20. Morris JC, Bergert ER, McCormick DJ. 1993 Structure-function studies of the humant thyrotropin receptor. J Biol Chem. 268:1090010905.

21. Baker J. 1993 Editorial: dissecting the immune response to the thyrotropin receptor in autoimmune thyroid disease. J Clin Endocrinol Metab. 77:16-18.

22. Heufelder AE, Bahn RS. 1992 Graves' immunoglobulins and cytokines stimulate the expression of intercellular adhesion molecule1 (1CAM) in cultured Graves' orbital fibroblasts. Eur J Clin Invest. 22:529-537.

23. Heufelder AE, Bahn RS. 1992 Evidence for the presence of a functional TSH receptor in retroocular fibroblasts from patients with Graves' ophthalmopathy. Exp Clin Endocrinol. 100:62-67.

24. Burch HB, Barnes S, Selletti D, Nagy E, Burman KD. Graves' retroocular fibroblasts contain protein which is immunogenically related but not identical to the thyrotropin receptor. Proc of the 75th Annual Meet of The Endocrine Soc. 1993;131.

25. Perros $\mathbf{P}$, Kendall-Taylor $\mathbf{P}$. TSH binding sites are present in orbital connective tissue and are recognized by IgGs from patients with thyroid-associated ophthalmopathy. Proc of the 66th Annual Meet of the Am Thyroid Assoc. 1992;544.

26. Roa BB, Garcia CA, Suter U, et al. 1993 Charcot-Marie-Tooth disease type IA-association with a spontaneous point mutation in the PMP22 gene. N Engl J Med. 329:96-101.

27. Ptacek LJ, George AL Jr, Griggs RC, et al. 1991 Identification of a mutation in the gene causing hyperkalemic periodic paralysis. Cell. 67:1021-1027.

28. Frecker M, Stenszky V, Balazc C, et al. 1986 Genetic factors in Graves' ophthalmopathy. Clin Endocrinol (Oxf). 25:479-485.

\section{7th Annual Meeting Society for the Study of Reproduction July 24-27, 1994 \\ University of Michigan, Ann Arbor, Michigan}

The 27th Annual Meeting of the Society for the Study of Reproduction will include a symposium on regulation of testicular and epididymal function. Michael Griswold, Anita Payne, and Bernard Robaire will be speakers. State-of-the-art lectures will feature the use of microdialysis in the study of reproductive mechanisms and implementing transgenic and embryonic stem cell technology to study gene expression and function and cell-cell interactions. Speakers will be Jane Robinson and Sally Camper. Deadline for submission of abstracts for poster and platform presentations is February 15, 1994. For additional information and abstract forms, contact Judith Jansen, Executive Secretary, SSR, 1526 Jefferson Street, Madison, WI 53711-2106. Telephone: 608-256-2777; FAX: 608-256-4610. 